\title{
A májátültetés aneszteziológiai-intenzív terápiás vonatkozásai
}

\author{
Fazakas János dr. - Smudla Anikó dr. \\ Semmelweis Egyetem, Általános Orvostudományi Kar, Transzplantációs és Sebészeti Klinika, Budapest
}

\begin{abstract}
Korunk egyik kiemelkedő eredménye a szervátültetés, mely a végstádiumú szervelégtelenségben szenvedő betegek egyetlen kezelési lehetősége. A transzplantációk sikeressége a donorgondozáson, a beteg műtéti előkészítésén, a szervátültetés perioperatív időszakán és az utógondozáson múlik. A sikeres transzplantáció ezért szükségessé teszi a sebész, az aneszteziológus, a radiológus, a belgyógyász-hepatológus, a labororvos és szinte valamennyi társszakma magas szintű, folyamatos együttmúködését. Az új kutatási eredmények alapján kialakított komplex interdiszciplináris szemléletnek köszönhetően célzott gyógyszeres kezeléssel, fizioterápiával, pszichoterápiával a beteg állapota javítható, konzerválható lesz a várólistán eltöltött időtartam alatt. A perioperatív graft resuscitatióban történő aktívabb, célzott terápiás lehetőségének megjelenése segítheti a jelenleg még nem transzplantálható rosszabb minőségű graftoknak már a recipiensen kívül (gépi perfúzió) vagy a recipiensben történő resuscitatióját, ezáltal a májtranszplantációk számának növekedését. A hemosztatikus folyamatok mélyebb megismerése a sebészeti technikák fejlődésével együtt növelné a vérkészítménymentes transzplantációk számát, így javítaná a graftok hosszú távú túlélését. A jelen összefoglaló tanulmány célja a májtranszplantáció anesztéziájának és korai intenzív terápiájának bemutatása az alkalmassági elbírálástól az altatáson át a korai intenzív terápiás kezelésig.
\end{abstract}

Orv Hetil. 2018; 159(46): 1891-1897.

Kulcsszavak: májtranszplantáció, anesztézia, intenzív terápia, májgraft

\section{Anesthetics and intensive therapeutic aspects of liver transplantation}

One of the most prominent results of our age is organ transplantation, the single treatment option for patients with end-stage organ failure. The success of transplants depends on the donor care, the patient preoperative preassessment, the perioperative care of organ transplantation and aftercare. Successful transplantation therefore requires a prominent level of continuous collaboration between the surgeon, anaesthesiologist, radiologist, internal medicine and hepatologist, laboratory physician and almost all their associates. The complex interdisciplinary approach based on the research results can be used to improve the patient's condition through pharmacotherapy, physiotherapy and psychotherapy during the time spent on waiting lists. The emergence of more active, targeted therapeutic options in perioperative graft resuscitation may help the currently inferior quality transplantable grafts or resuscitation out (machine perfusion) or in the recipient, thereby increasing the number of liver transplants. Deeper knowledge of hemostatic processes, along with the development of surgical techniques, would increase the number of blood transplant free transplants, thus improving the long-term survival of grafts. The present study aims at presenting the anaesthesia and early intensive therapy aspects of liver transplantation from aptitude assessment, through anaesthesia to early intensive therapeutic treatment.

Keywords: liver transplantation, anaesthesia, intensive care, liver graft

Fazakas J, Smudla A. [Anesthetics and intensive therapeutic aspects of liver transplantation]. Orv Hetil. 2018; 159(46): 1891-1897.

(Beérkezett: 2018. augusztus 20.; elfogadva: 2018. augusztus 31.)

\section{Rövidítések}

ACT $=$ (activated clotting time $)$ aktivált alvadási idő; $\mathrm{CCM}=$ (cirrhotic cardiomyopathy) cirrhoticus cardiomyopathia; $\mathrm{CI}=$ (cardiac index) szívindex; CVP $=($ central vein pressure $)$ centrá- lis vénás nyomás; $\mathrm{CVVH}=$ (continuous veno-venous hemofiltration) folyamatos venovenosus hemofiltráció; CVVHDF = (continuous veno-venous hemodiafiltration) folyamatos venovenosus hemodiafiltráció; DAMPs $=($ damage associated molec- 
ular patterns) sérüléshez kötött molekuláris mintázatok; $\mathrm{DO}_{2} \mathrm{I}$ $=($ oxygen delivery index $)$ oxigénszállítás indexe $; \mathrm{EKG}=$ elekt rokardiográfia; $\mathrm{ETCO}_{2}=\left(\right.$ end tidal $\left.\mathrm{CO}_{2}\right)$ kilégzésvégi széndioxid; EVLWI = (extravascular lung water index $)$ az extravascularis tüdôvíz indexe; $\mathrm{FeO}_{2}=$ kilélegzett oxigén aránya; $\mathrm{FiO}_{2}$ = belélegzett oxigén aránya; GEDVI = (global end-diastolic volume index) a globális végdiasztolés volumen indexe; HCV = hepatitis $\mathrm{C}$-vírus; $\mathrm{HE}=$ hepaticus encephalopathia; HPS = hepatopulmonalis szindróma; HRS = hepatorenalis szindróma; $\mathrm{INR}=$ (international normalized ratio) nemzetközi normalizált ráta; ITBVI $=$ (intrathoracic blood volume index $) \mathrm{az}$ intrathoracalis vérvolumen indexe; LMWH $=$ (low molecular weight heparin) alacsony molekulatömegű heparin; LW = LeeWhite-idő; MAP $=($ mean arterial pressure $)$ artériás középnyomás; PCWP = (pulmonary capillary wedge pressure $)$ pulmonalis kapilláris éknyomás; PDR-ICG = (plasma disappearance rate of indocyanine green) az indocianinzöld plazma eltűnési aránya; $\mathrm{PH}=$ portalis hypertonia; $\mathrm{pH}_{\mathrm{i}}=$ gyomor intramucosalis $\mathrm{pH} ; \mathrm{PPH}=$ portopulmonalis hypertonia; $\mathrm{PT}=($ prothrombin time) protrombinidő; $\mathrm{SpO}_{2}=$ oxigénszaturáció; $\mathrm{SVR}=$ (systemic vascular resistance) szisztémás vascularis rezisztencia

Korunk egyik kiemelkedő eredménye a szervátültetés, mely a végstádiumú szervelégtelenségben szenvedő betegek egyetlen kezelési lehetősége. Az 1995-ben indult magyarországi programban 2018 júniusáig 963 májátültetés történt $84,5 \%$ egyéves, $74,5 \%$ ötéves, $64,7 \%$ tízéves beteg-, illetve $83,1 \%-72,1 \%-61,3 \%$ grafttúlélés mellett. A transzplantációk sikeressége a donorgondozáson, a beteg mútéti előkészítésén, a szervátültetés perioperatív időszakán és az utógondozáson múlik. A sikeres szervátültetés ezért szükségessé teszi a sebész, az aneszteziológus, a radiológus, a belgyógyász-hepatológus, a laboratóriumi orvos és szinte valamennyi társszakma magas szintư, folyamatos együttmúködését.

Májtranszplantáció során a szervelégtelenség nem korlátozódik csupán az átülttetendő szervre. A májelégtelenség magával vonja a különböző társszervek súlyos funkciózavarát, amelynek végeredménye a preoperatív általános fizikai állapot súlyos leromlása. A májátültetés aneszteziológiai és intenzív terápiás vonatkozásai a következők: az aneszteziológiai alkalmasság elbírálása, a sikeres anesztézia kivitelezése és az intenzív terápiás kezelés.

\section{$\mathrm{Az}$ aneszteziológiai alkalmasság elbírálása}

Az aneszteziológiai alkalmasság elbírálása követi a szakma általános szabályait: a recipiens fizikális vizsgálata mellett a részletes kivizsgálása adatainak birtokában történik. A kivizsgálási protokoll szerinti preoperatív funkcionális tesztek felmérik a fiziológiás tartalékot, és kiszűrik azt a recipienst, aki kevésbé vagy nem alkalmas a májtranszplantációra [1-3].

A krónikus májelégtelenség a kiváltó májbetegséggel specifikusan és annak súlyosságával arányosan a társszervek funkciózavarához vezet (szív, tüdő, vese, idegrend- szer, vázizomzat), ezért az alkalmaság elbírálásakor a reverzibilis vagy irreverzibilis funkciózavarok diagnosztizálása rendkívüli fontos. A nem ischaemiás eredetû cirrhoticus cardiomyopathia fixált vagy minimálisan befolyásolható folyadék-, illetve inotrop terápiarezisztens perctérfogatot jelent, jelentősége a mútét alatti, vena cava inferior, illetve artériás conduit esetén az aorta kirekesztése következtében létrejövő extrém hemodinamikai terhelés miatt fontos [4-6]. A hepatopulmonalis szindróma a tüdő érhálózatában jelen lévő extrém vasodilatatio vagy esetenként lokalizált söntök formájában jelentkezik, jellemző tünete az orthodeoxia. Elhúzódó posztoperatív lélegeztetést és oxigénterápiát feltételez. A portopulmonalis hypertonia portalis és pulmonalis hypertensio együttes jelenléte; etiológiája összetett. Swan-Ganz-katéter segítségével történő méréssorozattal a következők tisztázandók: artériás vagy vénás, gyógyszeres kezelésre reagál vagy fixált, illetve hogyan viselkedik a kisvérköri volumen-, valamint vasopressorterhelésre [5-7]. A hepatorenalis szindróma a májbetegséghez társuló megváltozott hemodinamikai és neuroendokrin állapot következménye, lényegében vér- és áramlásszegény veseállapot, amely akár irreverzibilisen rosszabbodhat a különböző gyulladásos, infektív folyamatok, varixvérzések okán. Megléte esetén transzplantáció alatti folyamatos vesepótló kezelésre is szorulhat a beteg, ha a homeosztázis konzervatívan nem uralható $[5,6,8]$. A posztoperatív mortalitást szignifikánsan befolyásoló súlyos hepaticus encephalopathia elhúzódó intenzív osztályos kezelést prognosztizál $[5,6]$ (1. ábra).

$\mathrm{Az}$ extrahepaticus diszfunkciók algoritmusok szerinti korrigálása, perioperatív kezelése javítja a túlélést, ezért felismerésük az aneszteziológiai ambulancián akár vitális lehet. A transzplantációs listára engedett recipiensek az aneszteziológiai elbírálást követően, annak részeként perioperatív ellátási javaslattal is rendelkeznek.

\section{Az anesztézia kivitelezése}

A májriadó során az aneszteziológus a beteggel a premedikálás alkalmával találkozik. Az altatóorvos feladata a fizikális vizsgálat, a friss leletek áttekintése során a homeosztázis és a szervrendszerek aktuális állapotának felmérése, az akut extrahepaticus infekciók kizárása. A beteg elókészítésének főbb elemei a hasi, mellkasi röntgenvizsgálat, az ultrahang, a 6 óránál frissebb laboratóriumi vizsgálatok, illetve az alvadási status és a homeosztázis korrekciója.

A mûtét előtt anxiolysis céljából a beteg benzodiazepinszármazékot kap, igény szerint akár szedációs dózisban. A beteg antibiotikus profilaxist követően érkezik a mútőbe, ahol külső melegítése még az altatás előtt elkezdődik. A recipiensek májfunkciója primer, vesefunkciója szekunder módon beszúkülhet, így az alkalmazható gyógyszerek tulajdonságai is megváltozhatnak: a zsíroldékonyság, az ionizáltsági fok, a biotranszformáció, a metabolitaktivitás, az elimináció és a clearance is. Az al- 


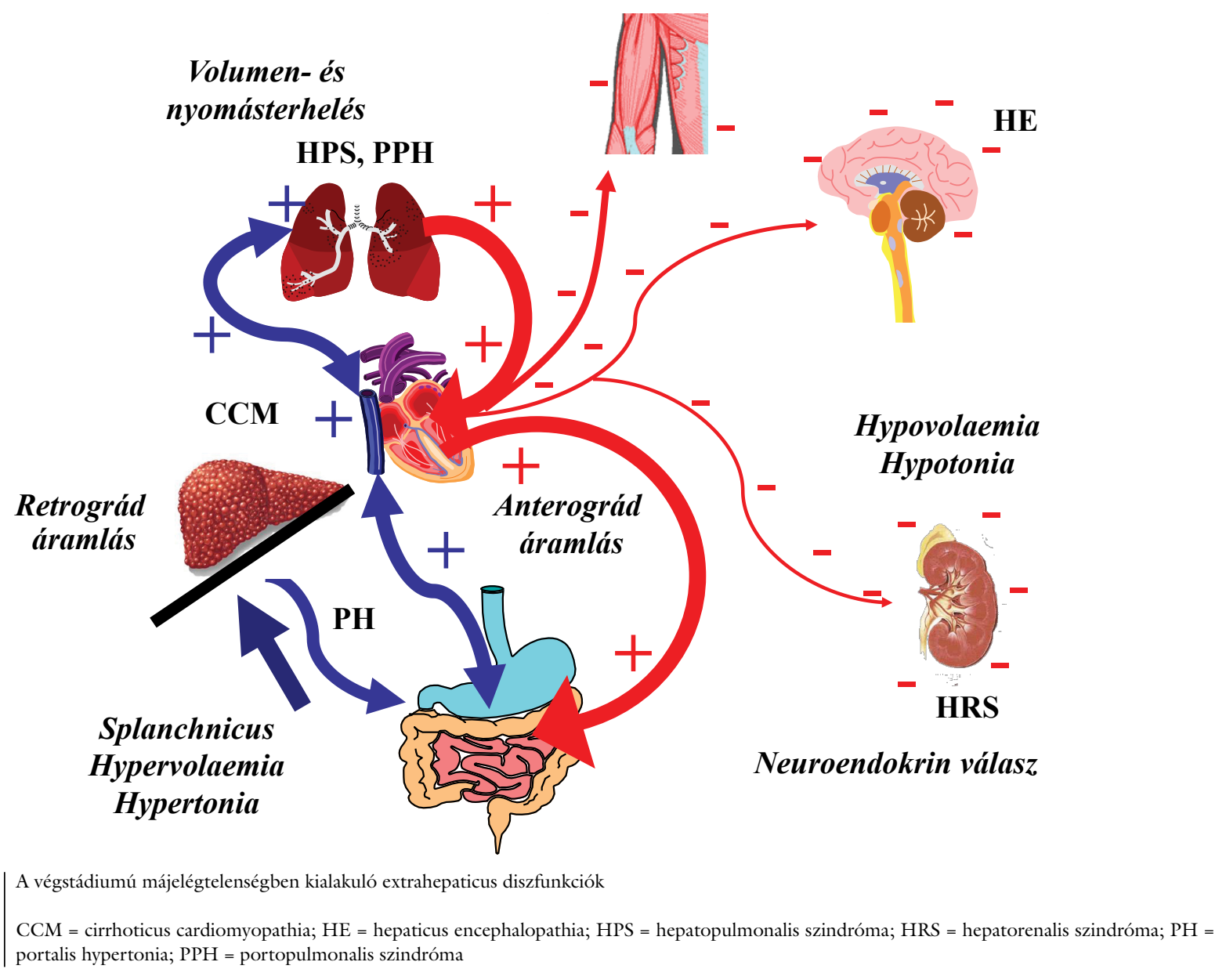

tatás, ellátás során alkalmazott gyógyszerek kiválasztása, adagolása a megváltozott farmakokinetika, farmakodinámia és az aktuális homeosztázis együttes átgondolása alapján történik. A szervi elégtelenségek függvényében az opioidok, a volatilis anesztetikumok dózisát célszerü titrálva 25-50\%-kal csökkenteni. Hypalbuminaemia, acidosis miatt megnő bizonyos barbiturátok, benzodiazepinszármazékok aktív frakciója, ezért 20-50\%-kal alacsonyabb dózist kell használni. A zsírban nem oldódó, magasan ionizált gyógyszerek közvetlenül a vesén keresztül választódnak ki, ezért dózisredukció szükséges; kivételt képez az atrakurium, a ciszatrakurium, a remifentanil és az ezmolol, mert extrarenalisan enzimatikusan, spontán bomlanak le. Az inhalációs anesztetikumok közül a szevoflurán bármely transzplantációs mútét anesztéziájához javasolható, mivel a legstabilabb hemodinamikai viszonyokat biztosítja, jelentős myocardiumprotekcióval rendelkezik, valamint opiátszármazékkal együtt adva ischaemiás prekondicionáló hatását is leírták $[5,6,8]$.

\section{Narkózisindukció és kanülálás}

Szokványos monitorizálás mellett (EKG, vérnyomásmérés, pulzoximetria) preoxigenizációt követően történik az elaltatás és az intubáció. A narkózis alatt a szem, illet- ve száj-ajak védelme fontos. Az aneszteziológus a narkózisindukció után, a mütét megkezdése előtt az invazív monitorizáláshoz szükséges kanülöket helyez a betegbe: centrális vénás és arteria radialis, illetve arteria femoralis (PiCCO) kanül, 2 vastag perifériás vénás kanül, gyomorszonda, hólyagkatéter. A mútét során elengedhetetlen a hemodinamikai status részletes invazív monitorozása (PiCCO, illetve Swan-Ganz-katéter - portopulmonalis hypertensio esetén), hogy a bekövetkezett változásokat időben regisztráljuk, a terápiát adekvát módon tudjuk vezetni. A narkózis során az egyes paramétereket folyamatosan figyeljük: EKG, CVP, ITBVI, CI és MAP, SVR, $\mathrm{DO}_{2} \mathrm{I}, \mathrm{SpO}_{2}, \mathrm{ETCO}_{2}, \mathrm{FiO}_{2}$ és $\mathrm{FeO}_{2}$, inhalációs anesztetikum be- és kilégzési koncentrációja, centrális hőmérséklet. Altatás alatt más paramétereket időszakosan óránként, szükség esetén gyakrabban mérünk: óradiuresis, artériás és centrális vénás vérgáz, vérkép, a szérum nátrium-, kálium-, ionizáltkalciumion- és laktátszintje, alvadási paraméterek (PT, ACT, viszkoelasztikus alvadási vizsgálatok - trombelasztográfia) $[5,6]$.

Súlyos hepatorenalis szindróma fennállásakor, illetve máj és vese kombinált átültetésekor, valamint hyponatraemia esetén intraoperatív folyamatos vesepótló $(\mathrm{CVVH}$, CVVHDF) kezelés javasolt a stabil homeosztázis fenntartása érdekében $[9,10]$. 


\section{Hepatectomia}

A laparotomia és a hepatectomia a narkózis fenntartása és igény szerinti mélyítése mellett történik. Általában 4060 perc áll az aneszteziológus rendelkezésére, hogy a homeosztázis (volaemia, ionia, hidria stb.) rendezése és megtartása mellett a vénás nyomást csökkentse a betegben. Optimális oxigenizációs és extrahepaticus perfúziós viszonyok megtartása mellett (laktát $<1,5 \mathrm{mmol} / 1$, óradiuresis $>1 \mathrm{ml} / \mathrm{kg}$ ) a májkivétel szempontjából kedvező hemodinamikai viszonyok biztosítása a cél: alacsony véna cava inferior nyomás $(\mathrm{CVP}=3-5 \mathrm{Hgmm})$, azaz a puha cava. A fenti célértékek elérése normovolaemia mellett a vénás vér redisztribúciója (a beteg melegítése és az antiTrendelenburg-testhelyzet), valamint az opiátok és az inhalációs anesztetikumok révén a sympathicotonia megszüntetése által lehetséges. A hasüregi visszerek nyomásának csökkentésére preoperatív hemodilució, illetve intraoperatív terlipresszinterápia alkalmazható. Az intraoperatív hypothermia megelőzése, kezelése létfontosságú, mert a mútét alatti lehúléssel arányosan a cirrhoticus beteg noradrenalin-vérszintje emelkedik, keringése átrendeződik, végtagi venoconstrictio alakul ki, a mobilis vérvolumen centralizálódik a hasba és a mellkasba, relatív mellkasi normovolaemia mellett magas töltőnyomásokat okozva. Ez sebészeti szempontból hátrányos, mivel az intraabdominalis és retroperitonealis visszerek és a vena cava inferior térfogatának és nyomásának megnövekedésével megnehezíti a hepatectomia elvégzését, növelve a vérveszteséget [11].

A hepatectomia alatt nagyfokú vérzéssel, a keringés és a folyadékterek átrendeződésével, keringéslabilitással és akár teljes keringés-összeomlással számolni kell, annak ellenére, hogy ennek gyakorisága az utóbbi időben világszerte lényegesen csökkent: előfordulása 20-30\% körül várható [12]. Nagyfokú vérzés kezelése koagulációs faktorok adásával, vérmentő eljárásokkal, vérkészítmények gyors infúziós rendszerrel történő pótlásával lehetséges. A coagulopathia megelózhetô a feljavított plazma elvének alkalmazásával. Megfelelő aneszteziológiai és sebészeti tapasztalat mellett a májtranszplantációk vérkészítménymentesen is elvégezhetők erre alkalmas recipiensekben $[5,6]$.

\section{Anbepaticus fázis}

A máj nélküli, azaz anhepaticus fázisra jellemző, hogy a szívhez visszaáramló vérmennyiség jelentősen csökken, a kirekesztés alatt a vena cava inferior és a portosplanchnicus területnek (vese-bél rendszer) megfelelően volumensequestratio alakul ki, a vénás nyomás akár 30-40 Hgmm-ig nőhet. A csökkent 'preload' miatt a globális és a regionális keringési feltételek romlanak, az oxigenizáció rosszabbodik. A vena cava inferior érvarrat elvégzését követően a portalis vénás érvarratok véglegesítése előtt a prezervációs oldatnak saját vérrel vagy $3-400 \mathrm{ml} \mathrm{5 \% -os}$ albuminoldattal való kimosása a mütét kötelező része [11] (2. ábra).

\section{Neobepaticus fázis}

A májtranszplantáció kritikus pillanata a cava felengedése és a donormáj portalis reperfúziója, azaz a neobepaticus fázis, amelynek során egyrészt a prezervált májból származó hideg, toxikus anyagok, másrészt a portosplanchnicus területen 'szekvesztrálódott' pangó vér a keringésbe kerül, és a jobb szívfél terhelését okozza, ezért súlyos pumpafunkció-zavar is kialakulhat. Ezzel párhuzamosan reperfúziós szindróma alakul ki hemodinamikai és hemosztatikus komponenssel. Hemodinamikai szempontból a globális keringés hiperdinám jellege a savanyú, hypoxiás metabolikus anyagok intravasalis jelenléte miatt tovább fokozódik, a pulmonalis erek tónusa nő, szemben a szisztémás vasoplegiával, kezelésük vénás noradrenalinnal, illetve inhalált prosztaciklinnel történik [11]. Hemosztatikus szempontból a hepatectomia alatti koagulációsfaktor-veszteség, -hígulás, -fogyasztás az anhepaticus fázis végén a reperfúziókor éri el mélypontját, ez részben reverzibilis (acidosis, hypothermia), részben irreverzibilis a mútétek 60\%-ában kialakuló primer fibrinolízis által. Kezelésük részben oki, részben szupportív, a szubsztrátumok visszapótlásával történik és viszkoelasztikus tesztekkel követhető. A bélbaktériumok transzlokációs, illetve ischaemiás-reperfúziós eredetû szisztémás gyulladás dinamikus felépülésével is számolni kell, ez betegenként

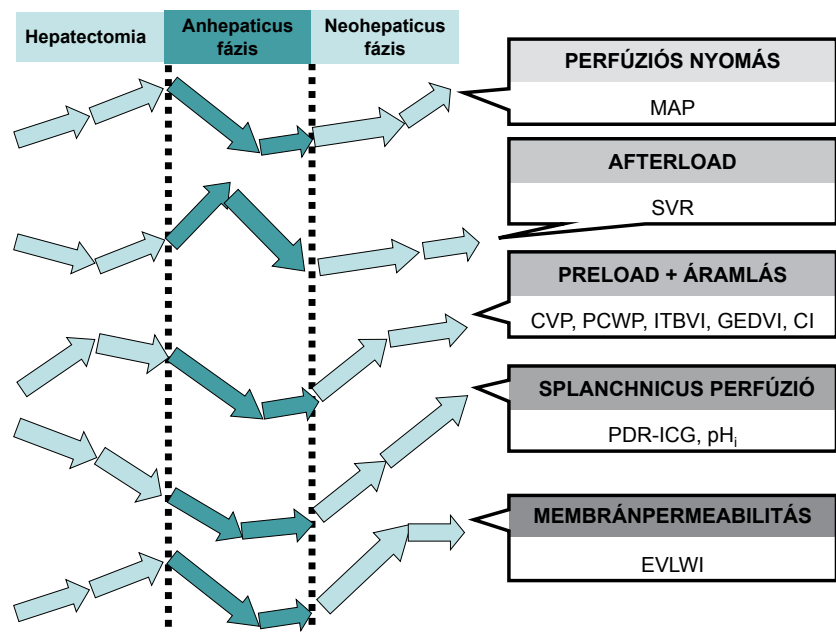

\begin{tabular}{l|l} 
2. ábra & $\begin{array}{l}\text { Hemodinamikai változások a májtranszplantáció során } \\
\mathrm{CI}=\text { szívindex; } \mathrm{CVP}=\text { centrális vénás nyomás; EVLWI = az } \\
\text { extravascularis tüdővíz indexe; GEDVI = a globális végdiasztol- } \\
\text { és volumen indexe; ITBVI = az intrathoracalis vérvolumen in- } \\
\text { dexe; } \mathrm{MAP}=\text { artériás középnyomás; } \mathrm{PCWP}=\text { pulmonalis kapil- } \\
\text { láris éknyomás; PDR-ICG = az indocianinzöld plazma eltúnési } \\
\text { aránya; } \mathrm{pHi}=\text { gyomor intramucosalis } \mathrm{pH} ; \mathrm{SVR}=\text { szisztémás } \\
\text { vascularis rezisztencia }\end{array}$
\end{tabular} 
eltérő. A máj nélküli állapot, illetve a hideg graft hasüregbe történő behelyezése és a keringésbe kerülése a maghőmérséklet további csökkenéséhez vezet [6].

A már vénásan keringő graft resuscitatiója az artériás keringés visszaadásával teljessé válik, ebben az időszakban elkerülendő a graft pangása, az aneszteziológiai aktivitás a regionális hemodinamikára, a lélegeztetésre, illetve a metabolikus kezelésre fókuszál. Az artériás reperfúziót követően intraoperatív ultrahangvizsgálat történik a graft keringésének detektálása céljából. Az epeúti varrat elkészítése, a gondos vérzéscsillapítás, a hasüreg drenálása, illetve a hasfalzárás ideje alatt rendeződni kezdenek a keringési, gázcsere- és hemosztatikus viszonyok, ezek kinetikáját követve igény szerint szupportív kezelés is alkalmazható.

A sikeres májtranszplantációt követően a beteget általában altatva, lélegeztetve, monitorizálva az intenzív osztályra szállítjuk. A ,fast-track” extubáció feltételei a kevés folyadékforgalom, a minimális vérigény, a 100\%-os sebészeti és aneszteziológiai siker, valamint egy korai 10 literes percventiláció teljesítése tekintettel arra, hogy ebben az időszakban az égési folyamatok igénye 50-100\%-kal megnő, és csak a posztoperatív 12. órára normalizálódik $[13,14]$.

\section{Intenzív osztályos kezelés}

A recipiens posztoperatív kezelését meghatározó tényezők közé tartozik a beteg életkora, a mútét előtti állapota, a beültetett graft állapota (donor risk index, hideg- és melegischaemiás idők, a donor hypotensiv időszakának hossza), a sebészi (mütéti idő, anasztomózisok, vérvesztés) és az aneszteziológiai (hemodinamikai, koagulációs, homeosztatikus stabilitás) sikeresség [15-17].

\section{Korai posztoperatio szak}

Már a mütőben jelentkezik a reperfúziós ártalom, amelyet a prezerváció, a hideg- és melegischaemia során kialakult hypoxiás stressz indít el. Az ischaemia következtében szabaddá váló sérüléshez kötött molekuláris mintázatok (damage associated molecular patterns; DAMPs) indukálják a gyulladásos válaszreakciót, amelynek dinamikus növekedése törvényszerü, csak a mértéke kérdéses - ez utóbbi a folyamat számos összetevőjétől függ. A folyamatban szereplő tényezők hatása összetett, és hozzájárul a graft véráramlásának csökkenéséhez. Sokszor az ellentétes hatású anyagok helyi aránya is változik, ami inhomogenitást okoz. A reperfúziós ártalom kezdetben csak a beültetett szervre lokalizálódik: megnő a graft érellenállása, romlik az oxigenizációja, interszticiális ödéma alakul ki. Esetenként a graftból a folyamat kiterjedhet az egész szervezetre [6].

Az intenzív osztályon kezdetben a mútói körülményeknek megfelelően folytatjuk a megfigyelést, a folyamatosan mért paramétereken kívül az időszakosan mért paraméte- reket kezdetben óránként, majd 3 óránként ellenőrizzük. A májtranszplantált beteget 6 óránként fizikálisan megvizsgáljuk, a szövődménylehetőségeket kizárjuk. A teljes siker érdekében lényeges, hogy a kezelést végző személyzet veszélyérzete ne tompuljon, amikor lényeges vérveszteség nélküli májtranszplantáció történt [17].

A korai posztoperatív időszakban a mütét sikerességétôl és a graft múködésétől függóen a keringési viszonyok normalizálódnak, a reperfúziós szindrómára jellemző hiperdinám keringési állapot a posztoperatív 3-4. napra szűnik meg. A megfelelő perfúziós nyomás biztosítására elsőként a noradrenalin alkalmazása javasolt, általában a mütét utáni első napon a vasopressorkezelés leépíthető. A hemodinamikai kezelés célja fenntartani a megfelelő perctérfogatot és perfúziós középnyomást, alacsony centrális vénás nyomás mellett [11].

A beteg lélegeztetését eleinte kontrolláltan, majd aszszisztáltan végezzük. A szervrendszerek fizikális, laboratóriumi és képalkotókkal történő ellenőrzését követően a stabil állapotú beteget jól múködő grafttal, jelentős belszervi tartalékokkal, kompenzált homeosztázissal, megfelelő tudatállapot mellett extubáljuk. Ezt követően a légzési fizioterápia kiemelten fontos. A gépi lélegeztetés megszüntetésének feltételei a graft múködési elégtelenségétől eltekintve nem transzplantációspecifikusak. A fájdalomcsillapítás, a stresszulcus és az antibiotikus profilaxis, a légzési fizioterápia hasonló, mint egyéb felső hasi mútétek után $[2,5,17]$.

A posztoperatív laboratóriumi vizsgálatok szövődménymentes esetben citolitikus májenzim-kimosódást, jó exkréciós és szintetikus aktivitást mutatnak, a beültetett máj kvalitásának függvényében az első hét végére a laboratóriumi paraméterek normalizálódnak. A mütét utáni ultrahangvizsgálatok tájékoztatnak a graftperfúzió mértekéről, illetve minőségéről és a mütéti felszínek környékén lévő folyadékmennyiségről.

Az éranasztomózisok után az optimális koagulációsantikoagulációs egyensúlyt nátrium-heparin és antitrombin-III kombinációjának adásával biztosítjuk, később egyensúlyban lévő haemostasis mellett LMWH adására térünk át, számításba véve a graft szintetizálókapacitását is. A véralvadás vizsgálata laboratóriumi kontrollvizsgálatokkal, viszkoelasztikus tesztekkel (TEG, ROTEM), LW, ACT és INR 'bed-side' mérésekkel történik. A thrombocytaaggregáció vizsgálata esetenként fontossággal bír, a posztoperatív vérzés, illetve artériás éranasztomózisok thrombosisa elkerülése érdekében $[2,17]$.

Az első 3 nap gyógyszeres kezelése az akut májelégtelenségben szenvedő betegek májvédő jellegú stratégiáját követi. A mútét után átmenetileg parenteralis táplálást alkalmazunk, majd a bélmúködés helyreállása után enteralis táplálást, illetve per os táplálást vezetünk be. Az immunszuppresszió az operatőrrel, hepatológussal egyeztetve történik, tekintetbe véve a transzplantáció okozta endogén immunszuppresszió dinamikáját és a graft- és vesefunkciót is; a gyógyszerszinteket természetesen monitorizáljuk. Szövődménymentes esetben három-négy 
napi intenzív kezelés után a májtranszplantált beteget sebészeti osztályra helyezzük, és törekedünk az invazív eszközök minél korábbi eltávolítására.

\section{Posztoperatín szövődmények}

A graft kezdeti elégtelensége vagy teljes múködésének hiánya életet veszélyeztető szövődmény, etiológiája és kezelése komplex, sikertelensége esetén a beteget stabilan kell tartani a retranszplantációig. Speciális állapotot teremt tehát a károsodott graft, amely tovább serkenti a gyulladásos-koagulációs kaszkádot. Ebben az esetben a túlméretezett, egyensúlyát vesztett védekezési folyamatok többszervi elégtelenséget okozhatnak. A keringési elégtelenség hiperdinám disztributív formája alakulhat ki, mely az előbb említett folyamatok következménye. A glycocalix sérülése és funkcionális elégtelensége progresszíven kialakuló ödémát és túlsúlyt hoz létre. A folyamatos vesepótló kezelés, esetenként CytoSorb ${ }^{\circledR}$ filterrel végzett citokinadszorpció segíthet az egyensúlyzavarok helyreállításában, továbbá a graft és az általános ödéma csökkentésében [18, 19].

A fertőzéses szövődmények előfordulása, típusa, kezelése hasonló, mint a májműtéten átesett betegeknél, azzal a különbséggel, hogy a májtranszplantáltaknál az exogén immunszuppresszió mértéke az endogén immunszuppresszió dinamikájához igazodik, és együttesen biztosítanak egy rejekciómentes állapotot [20].

\section{Jövőkép}

Az új direkt ható antivirális gyógyszerek megjelenésével a májelégtelen betegek etiológiai háttere megváltozik, a HCV miatt transzplantálandók száma várhatóan csökkenni fog [21]. A jövőben várható a májbetegség és az asszociált extrahepaticus diszfunkciók hátterének részletesebb tisztázása, ami elősegítheti a korai felismerést és a célzott terápia megkezdését, így a várólistára a betegek korábban, jobb általános állapotban kerülhetnek fel. A patomechanizmusokat tisztázó új kutatási eredmények alapján kialakított komplex interdiszciplináris szemléletnek köszönhetően célzott gyógyszeres kezeléssel, fizioterápiával, pszichoterápiával a beteg állapota javítható vagy legalább konzerválható lesz a várólistán eltöltött időtartam alatt. A perioperatív graftresuscitatióban történő aktívabb, célzott terápiás lehetőségek megjelenése segítheti a jelenleg még nem transzplantálható rosszabb minőségű graftoknak már a recipiensen kívül (gépi perfúzió) vagy a recipiensben történő resuscitatióját, ezáltal a májtranszplantációk száma növekedhetne. A hemosztatikus folyamatok mélyebb megismerése a sebészeti technikák fejlődésével együtt növelné a vérkészítménymentes transzplantációk számát, így javítaná a graftok hosszú távú túlélését.
Anyagi támogatás: A közlemény megírása és a kapcsolódó kutatómunka anyagi támogatásban nem részesült.

Szerzôi munkamegosztás: F. J.: Irodalomkutatás, a publikáció szövegezése és szerkesztése. S. A.: Irodalomkutatás, a publikáció szövegezése. A cikk végleges változatát mindkét szerző elolvasta és jóváhagyta.

Érdekeltségek: A szerzőknek nincsenek érdekeltségeik.

\section{Irodalom}

[1] Kóbori L, Görög D, Fehérvári I, et al. Progress of the liver transplantation programme in Hungary. [A hazai májátültetési program fejlődése.] Orv Hetil. 2013; 154: 858-862. [Hungarian]

[2] Beattie C, Gillies MA. Anaesthesia and intensive care for adult liver transplantation. Anaesth Intensive Care Med. 2015; 16: 339-343.

[3] Megyaszai S, Darvas K, Karácsonyi S, et al. Anaesthesia of liver transplantation. [A májtranszplantáció aneszteziológiai vonatkozásai.] Aneszt Int Ter. 2012; 42: 227-229. [Hungarian]

[4] Walker CP, Harris P, Fazakas J, et al. The transplanted patients: can we improve outcomes of non-transplant surgery? In: Fellahi JL, Leone M. (eds.) Anesthesia in high-risk patients. Springer, Cham, 2017; pp. 271-284.

[5] Fazakas J, Mándli T, Ther G. Transplantation anaesthesia. In: Bogár L. (ed.) Anaesthesia and intensive care. [Transzplantációs anesztézia. In: Bogár L. (szerk.) Aneszteziológia és intenzív terápia.] Medicina Könyvkiadó, Budapest, 2014; pp. 338-342. [Hungarian]

[6] Fazakas J, Smudla A. Anaesthesia of pediatric solid organ transplantation. In: Ujhelyi E, Kövesi T. (eds.) Theory and practice of pediatric anaesthesia. [Gyermekkori szervtranszplantációk anesztéziája. In: Ujhelyi E, Kövesi T. (szerk.) A gyermekaneszteziológia elmélete és gyakorlata.] Medicina Könyvkiadó, Budapest, 2015; pp. 957-969. [Hungarian]

[7] Krowka MJ, Fallon MB, Kawut SM, et al. International Liver Transplant Society Practice Guidelines: Diagnosis and management of hepatopulmonary syndrome and portopulmonary hypertension. Transplantation 2016; 100: 1440-1452.

[8] Keegan MT, Kramer DJ. Perioperative care of the liver transplant patient. Crit Care Clin. 2016; 32: 453-473

[9] Gámán G, Gelley F, Gerlei Z, et al. Kidney function and liver transplantation. [Veseérintettség májátültetés során.] Orv Hetil. 2013; 154: 1018-1025. [Hungarian]

[10] Larsson JS, Bragadottir G, Redfors B, et al. Renal function and oxygenation are impaired early after liver transplantation despite hyperdynamic systemic circulation. Crit Care 2017; 21: 87.

[11] Fazakas J, Doros A, Smudla A, et al. Volumetric hemodynamic changes and postoperative complications in hypothermic liver transplanted patients. Transplant Proc. 2011; 43: 1275-1277.

[12] Massicotte L, Denault AY, Beaulieu D, et al. Transfusion rate for 500 consecutive liver transplantations: experience of one liver transplantation center. Transplantation 2012; 93: 1276-1281.

[13] Aniskevich S, Pai SL. Fast track anesthesia for liver transplantation: review of the current practice. World J Hepatol. 2015; 7: 2303-2308.

[14] Biancofiore G, Tomescu DR, Mandell MS. Rapid recovery of liver transplantation recipients by implementation of fast-track care steps: what is holding us back? Semin Cardiothorac Vasc Anesth. 2018; 22: 191-196.

[15] Nemes B, Gelley F, Zádori G, et al. Outcome of liver transplantation based on donor graft quality and recipient status. Transplant Proc. 2010; 42: 2327-2330. 
[16] Hofer I, Spivack J, Yaport M, et al. Association between anesthesiologist experience and mortality after orthotopic liver transplantation. Liver Transpl. 2015; 21: 89-95.

[17] Fazakas J, Smudla A, Rengeiné Kiss T. Pediatric intensive care after solid organ transplantation. In: Ujhelyi E. (ed.) Theory and practice of pediatric intensive care. [Gyermekkori szervtranszplantációk intenzív terápiája. In: Ujhelyi E. (szerk.) A gyermekintenzív ellátás elmélete és gyakorlata.] Medicina Könyvkiadó, Budapest, 2014; pp. 167-171. [Hungarian]

[18] Clària J, Stauber RE, Coenraad MJ, et al. Systemic inflammation in decompensated cirrhosis: characterization and role in acuteon-chronic liver failure. Hepatology 2016; 64: 1249-1264.

[19] Tomescu DR, Dima SO, Ungureanu D, et al. First report of cytokine removal using CytoSorb ${ }^{\circledR}$ in severe noninfectious inflam- matory syndrome after liver transplantation. Int J Artif Organs 2016; 39: 136-140.

[20] Nemes B, Gelley F, Dabasi E, et al. Bacterial infection after orthotopic liver transplantation. [Bakteriális infekciók májátültetés után.] Orv Hetil. 2015; 156: 1366-1382. [Hungarian]

[21] Hunyady B, Gerlei Z, Gervain J, et al. Diagnosis, treatment, and follow-up of hepatitis $\mathrm{C}$ virus related liver disease. National consensus guideline in Hungary. [Hepatitis C-vírus-fertózés: diagnosztika, antivirális terápia, kezelés utáni gondozás. Magyar konszenzusajánlás.] Orv Hetil. 2015; 156: 343-351. [Hungarian]

(Fazakas János dr., Budapest, Baross u. 23-25., 1083 e-mail: jancsidora@gmail.com)

\section{A LEGÚJABB, AMBULÁNSAN VÉGEZHETŐ MINIMÁL INVAZÍV ELJÁRÁSOK ELÉRHETŐEK HAZÁNKBAN:}

\section{| Jóindulatú pajzsmirigy göb rádiófrekvenciás ablációja Fibroadenóma krioablációja}

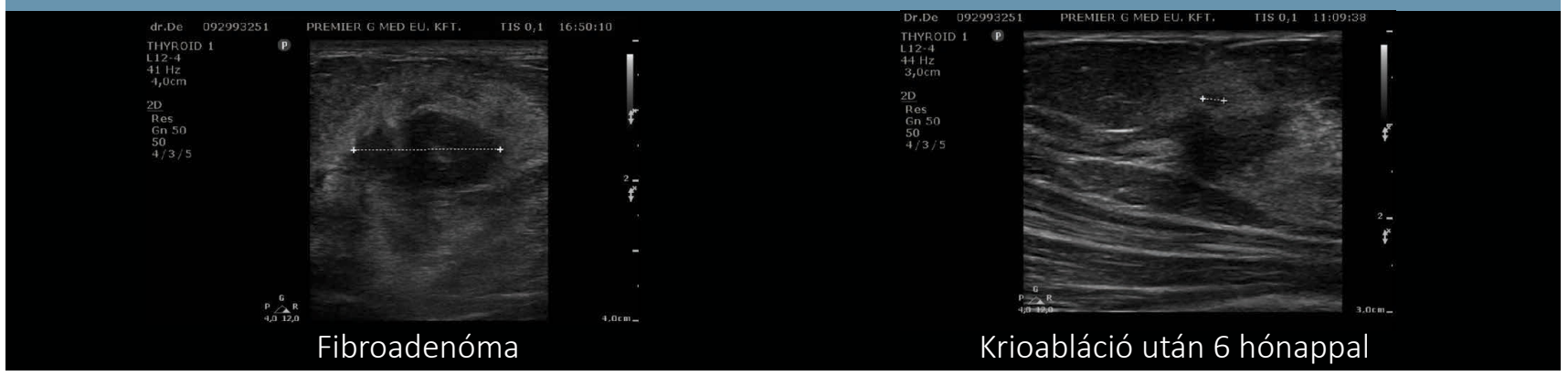

A részletekről érdeklődjön egészségügyi kapcsolattartónknál, Tóth Csillánál a csilla.toth@premiergmed.hu-n vagy a 0620849 5524-es számon. www.premiermed.hu

PREMIER MED

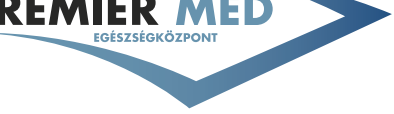

A cikk a Creative Commons Attribution-NonCommercial 4.0 International License (https://creativecommons.org/licenses/by-nc/4.0) feltételei szerint publikált Open Access közlemény, melynek szellemében a cikk nem kereskedelmi célból bármilyen médiumban szabadon felhasználható, megosztható és újraközölhető, feltéve, hogy az eredeti szerző és a közlés helye, illetve a CC License linkje és az esetlegesen végrehajtott módosítások feltüntetésre kerülnek. 